Journal of Critical Race Inquiry

Volume 7, Number 2 (2020) pp. 74-96

\title{
Rendering Whiteness Palatable: The Acceptable Muslim in an Era of White Rage
}

Shelina Kassam

Independent Scholar

Abstract: In this paper, I analyze the perspectives of the Acceptable Muslim (Kassam, 2018) in two Canadian case studies: (a) Irshad Manji, a Canadian Muslim journalist and activist who has been an active commentator on a variety of issues including those related to Muslims; and (b) the CBC sitcom Little Mosque on the Prairie (2007-2012), which was the first Canadian mainstream television series featuring Muslim characters. I suggest that these case studies illuminate the figure of the Acceptable Muslim (Kassam, 2018) who is represented as a "moderate," modern, and assimilable Muslim, and who espouses a privatized faith with few public expressions of religious/cultural belonging. Centrally implicated in Canadian debates about multiculturalism, gender equality, citizenship, and secularism, Acceptable Muslims (re)confirm the racial boundaries of the nation-state, becoming icons of multiculturalism, reanimating the whiteness at the heart of the Canadian nation-state. The Acceptable Muslim sustains the narrative of the Canadian nation-state as liberal, secular, modern, and inclusive even as it relentlessly excludes, punishes, and eliminates the Muslim Other, enabling such policies to be legitimated as "race-neutral." Acceptable Muslims stand as sentries at the (symbolic) borders of the nation, reanimating racialized boundaries of acceptability and signalling that those beyond these boundaries can be legitimately policed by the nation-state. My analysis provides insights into how Canada has re-configured the power and persistence of its white fantasy and, through the strategic use of the Acceptable Muslim, cloaks its deeply racialized coding in more palatable grammars of multiculturalism, gender equality, and secularism. 
Keywords: Muslims, Islamophobia, whiteness, white rage, multiculturalism, Irshad Manji, Little Mosque on the Prairie

\section{Introduction}

The notion of Muslimness is deeply entrenched in post 9/11 national and international discourses, which situate the visibly Muslim Other as barbaric, dangerous, oppressed/oppressive (depending on gender), and uncivilized; a body that must be surveilled and, if necessary, expelled from civilized Western society. In an era of white rage and a reanimation of white supremacy, visibly Muslim bodies are often the target of angst over multicultural boundaries; these visibly Muslim bodies - mostly racialized ones - are at the heart of many contestations, rendering these bodies as hyper-visible and as sites of threat against an increasingly hostile (mostly white) Western public. Based on classic Orientalist imaginaries (Said, 1978/2003; Yegenoglu, 1998), these tropes about Muslims reanimate boundaries of acceptability within Western society, boundaries which situate some (mostly white bodies) within, and others (mostly racialized bodies) outside the bounds of so-called "civilized" society. Deeply rooted in histories of domination and subordination, these boundaries of acceptability shape the material and symbolic realities of citizenship, with some subjects encountering a "fragility of belonging" (Volpp, 2012, p. 467). While Indigenous and racialized bodies have long been positioned outside the boundaries of the Canadian settler state, in the contemporary context, Muslims (often racialized and gendered) are also situated outside these boundaries, "cast out of political community" (Razack, 2008) and experience a tenuous hold on citizenship. In Canada, Muslims have been at the heart of these public contestations since at least 2007. For instance, Quebec's Bill 21, passed in June 2019, prohibits provincial public sector employees from wearing religious symbols. Such a law is likely targeted at Muslim women who, along with Sikh and Jewish men, are most affected by the law. Federal political leaders, possibly fearing electoral backlash, have shown reluctance to stand against such discriminatory legislation. Such public contestations, including challenges about Muslim women's clothing (in courts, citizenship ceremonies, educational institutions, sports competitions) or proposals about using Muslim Law in arbitration reflect how Muslims are perceived to test the limits of Western secular and multicultural society. In an era of white rage, much angst has been focused on visible Muslims, who are perceived as threats to Western norms and against whom white rage is often directed. 
Against the backdrop of these contemporary contestations and in the midst of white rage, I trace the emergence of a less visible figure: the Acceptable Muslim (Kassam, 2018), who is depicted as modern and assimilable, one who espouses a privatized faith with few public expressions of religious or cultural belonging. This figure, referred to elsewhere as the "moderate Muslim"1 (though the term is problematic), appears consistently in post 9/11 Western public discourses, and is juxtaposed against the Muslim Other who is depicted as a physical and symbolic threat to Western society and norms. The term "Acceptable Muslim" (Kassam, 2018) denotes that this figure must be perceived as acceptable and legitimate by the hegemonic elite in Western nation-states. These Acceptable Muslims publicly support Western ideological goals and norms - ranging in tone from diplomatic to fierce - and they sustain the image of the Canadian nation-state as liberal, secular, and inclusive, even as the state marginalizes, punishes, excludes and, where necessary, expels the Muslim Other. In an era of white rage, Acceptable Muslims enable the nation-state to implement deeply problematic policies while inoculating itself against charges of racism, Islamophobia, and antiMuslim racism. Acceptable Muslims, therefore, reanimate the Canadian national imaginary, in which the fantasy of white space (Hage, 2000) is central and enables "a new kind of racism, one that projects antiracism and multiculturalism on the surface but simultaneously produces the logics and affects necessary to legitimate racist policies and practices" (Alsultany, 2012, p. 16).

The perspectives of Acceptable Muslims, I argue, situate them either as Secular Acceptable Muslims or Multiculturalist Acceptable Muslims (Kassam, 2018). Acceptable Muslims, both Secular and Multiculturalist, share five attributes of acceptability: 1) they urge public condemnation of extremism; 2) they essentialize Muslims, albeit in different ways; 3 ) they reaffirm secular normativity; 4) they focus on gender (in)equality; and 5) they engage with Canadian multiculturalism, either through endorsing or critiquing its norms. While their perspectives have some distinctions - hence, the distinction between Secular and Multiculturalist - these Acceptable Muslims perform similar ideological work in the context of a white settler nation-state such as Canada. In this paper, I analyse the perspectives of two case studies in which attributes of Acceptable Muslims are evident: first, Irshad Manji, a journalist and social commentator who I argue is a Secular Acceptable Muslim and second, the CBC sitcom Little Mosque on the Prairie (LMOP), which centres Multiculturalist Acceptable Muslims perspectives. I focus in this paper on two attributes of acceptability of

\footnotetext{
1 I challenge the term "moderate Muslim" because it reconfirms Orientalist depictions of Muslims as radical, barbaric, and dangerous. The use of "moderate" as a qualifier implies that the "moderate Muslim" is the exceptional Muslim; it is a qualifier that situates the Muslim (without the qualifier) as always-already radical, violent and immoderate.
} 
Acceptable Muslims: namely, their engagement with Canadian multiculturalism and their focus on gender (in)equality. These two attributes illuminate how, in this era of white rage, Acceptable Muslims reaffirm key elements of the Canadian national narrative, a mythology rooted in racial coding and whiteness.

\section{Gendered Orientalism and the Fantasy of White Space}

My analysis of the Acceptable Muslim is animated by postcolonial and feminist analyses on gendered Orientalism, racialization, and citizenship. Extending the work of Said (1978/2003, 1981) and Yegenoglu (1998) on Orientalism and gendered Orientalism, numerous scholars have written about the racialized Muslim body in the context of Western nation-states (Hage, 2000; Jiwani, 2009, 2011a, 2011b, 2014, 2017; Karim, 2000; Lentin, 2008, 2015; Maira, 2009; Naber, 2008; Rana, 2007, 2016; Razack, 2008, 2012, 2014, 2018; Thobani, 2007, 2014; Volpp, 2002, 2005, 2007a, 2007b; Zine, 2012). Contemporary hegemonic discourse depicts Muslims (or anyone who "looks Muslim") as the epitome of danger, violence, and extremism, situated outside the boundaries of citizenship and positioned as threats to Western civilization. The deployment of race, embedded in classic Orientalist imagery, is enlisted to reaffirm these racialized societal boundaries and to justify a racially ordered world (Razack, 2008, p. 6), in which the community of white nations maintains its dominance. Mamdani's (2004) notion of the "good Muslim" complicates the Orientalist imagery of Muslims as exotic, primitive, child-like, and threatening. Building on these ideas, Alsultany (2012), Bayoumi (2010), Dabashi (2011), Kundnani (2014), Sharify-Funk (2010, 2013), Shryock (2010) and others pay attention to the figure of the sympathetic Muslim who is situated as "moderate," modern, assimilable, and who does not display visible signs of Muslimness. These scholars theorize that such a good Muslim body, juxtaposed against the racialized, threatening "bad Muslim" (Mamdani, 2004) is depicted sympathetically as an ally of the Western nation-state.

Gender is central to the Orientalist imaginary, with gender being the most urgent terrain in the contemporary context through which Muslims are judged. Razack (2008) argues that it is "through gender that we can tell the difference between those who are modern and those who are not" (Razack, 2008, p. 17). Foundational to contemporary Orientalist imaginaries are three allegorical figures that comprise the "eternal triangle" (Razack, 2008). These figures are "the dangerous Muslim man, the imperilled Muslim woman, and the civilized European, the latter who is seldom explicitly named but who nevertheless anchors 
the first two figures" (Razack, 2008, p. 5). Jiwani (2009) suggests that Muslim women are represented as "helpless victims," with Western bodies positioned as "civilized knights" who must save oppressed Muslim women. I argue that Acceptable Muslims complicate the eternal triangle, gaining qualified inclusion in the Canadian national imaginary, by becoming insider informers and the newest members of the "civilized knights" saving Muslim women from their supposedly oppressive traditions.

Numerous scholars theorize that citizenship is racially coded and that the boundaries of inclusion regulate the privileges of citizenship (Ahmed, 2000; Balibar \& Wallerstein, 1988/2005; Goldberg, 2009; Hage, 2000; Razack, 1999, 2001, 2008, 2002; Thobani, 2007; Volpp, 2002, 2005, 2007a, 2007b). Embedded in narratives about citizenship are scripts about race, gender, space, and culture, all of which shape the boundaries of political and civic engagement. Citizenship ultimately defines boundaries between "us" and "them," positioning some bodies within the boundaries of the nation-state and deserving of the rights of belonging, with other bodies situated outside these boundaries and excluded from such privileges. As Yuval-Davis writes, such "construction of boundaries, of a delineated collectivity, that includes some people - concrete or not - and excludes others, involves an act of active and situated imagination" (2006, p. 204). This is the "imagined political community" (Anderson, 1983 ) through which modern nation-states "produce the people" (Balibar \& Wallerstein, 1988/2005, p. 93). Hage (2000) argues that a fantasy of white space animates the Western nation-state, and its subjects' sense of belonging to the nation. He further suggests that this fantasy undergirds both openly race-based practices and multicultural policies of the Western nation-state. Thus, while racist practices and multiculturalist ideals may appear contradictory, Hage (2000) observes that "White racists and White multiculturalists share in a conception of themselves as nationalists and of the nation as a space structured around a White culture, where Aboriginal people and non-White 'ethnics' are merely national objects to be moved or removed according to a White national will" (p. 18). This is "a fantasy of a nation governed by White people, a fantasy of White supremacy" (Hage, 2000, p. 18). Hage's (2000) analysis demonstrates that racist practices of exclusion and multiculturalism's practices of "tolerance" share the same underlying fantasy - that of the whiteness of public space controlled by a (white) national subject enjoying a privileged relationship to the nation-state. This managerial capacity - one of power to define the terms by which national belonging is negotiated and understood - is at the heart of white rage, with its perception that the nation is not what it "ought" to be. Thus, distinctions between racist policies of exclusion and multicultural policies of inclusion are superficial; both sets of policies are set on terms established by the racial coding of the nation-state. These terms establish racially coded boundaries of 
acceptability that determine which subjects (and behaviours) are included in the national imaginary. Laments that "multiculturalism has gone too far" imply that these boundaries of acceptability have been violated by racialized Others and the power and privilege of the (white) national subject challenged. Such claims speak powerfully to the sense of threat and entitlement — white rage — of the empowered national subject.

\section{Research Design, Data, and Methodology}

My research design is shaped by an interrogation of power, privilege, and domination in contemporary Canadian society, and an analysis of what (and who) is produced by such hegemonic relations. My analysis in this paper is based on a larger project which consists of a study of Canadian media discourses over a decade (January 2005 to December 2014) about Muslims as well as a detailed analysis of the perspectives of four Acceptable Muslims who appear consistently in Canadian discourses. In this paper, I analyze two case studies - the pronouncements of journalist and public commentator, Irshad Manji, and Little Mosque on the Prairie (LMOP) — which embody attributes of the Acceptable Muslim. I focus on two attributes of acceptability, which illuminate how these Acceptable Muslims solidify and reanimate whiteness at the heart of the national imaginary. These standards of acceptability are evident in Manji's work and in LMOP, the former reflecting perspectives of Secular Acceptable Muslims, and the latter of Multiculturalist Acceptable Muslims. I consider Manji's media footprint as well as samples of her work, and analyze the representations in $L M O P$, the first Canadian mainstream television sitcom featuring Muslims. I also consider, where appropriate, the work of Zarqa Nawaz, the creator of Little Mosque on the Prairie, especially because Nawaz's influence is deeply embedded on the sitcom.

In my analysis, I rely on Critical Discourse Analysis (CDA), a multidisciplinary, qualitative approach that uses discourse, language use, and communication to examine social and political issues (Van Dijk, 2008). CDA enables me to interrogate Acceptable Muslims and their work within discourses of power, privilege, hegemony, and domination. CDA posits that power and privilege reside in texts and in textual silences, illuminating the power relations embedded in language and discourse. 


\section{Reanimating Racial Coding: Irshad Manji as a Secular Acceptable Muslim}

\section{Introduction}

Irshad Manji was born in Uganda in 1968 and moved to Canada in the early 1970s, growing up in British Columbia, and living in Toronto before moving to the United States. She is a journalist, writer, and activist who has been a commentator on numerous issues, including those related to Muslims, multiculturalism, and the rights of gays and lesbians. She is the author of three books, The Trouble with Islam (2005), Allah, Liberty and Love (2011), and Don't Label Me (2019), and the producer of a documentary, Faith Without Fear (2007). She is well-known for calling for an "Islamic Reformation" (Manji, 2005, p. 3) and refers to herself as a "Muslim refusenik" (Manji, 2005, p. 3), a term saturated with political meaning. She is the founder of the Moral Courage Project (now renamed the Moral Courage College). ${ }^{2}$

Manji presents a hard-line version of acceptability that positions the visibly Muslim body as too "different" from Western norms, situating such bodies outside the bounds of the Western imaginary. Such a positioning of visibly Muslim bodies, based on Western norms, reanimates the fantasy of white space, with the (white) exalted subject (Thobani, 2007) or national manager (Hage, 2000) at the centre of public space, able to define, manage, and control the Indigenous and racialized Other. I argue that Secular Acceptable Muslims such as Manji explicitly ally themselves with the exalted subject (Thobani, 2007) and gain qualified inclusion in the national imaginary. White rage - rooted in both the empowerment and threat felt by the white national subject - is directed at Indigenous and racial Others who are presumably situated outside the boundaries of Western society. Like other Secular Acceptable Muslims, Manji's perspectives reinforce these racialized boundaries, anointing these boundaries (and their exclusions) as legitimate and non-racist, because of her positioning as an insider informer and racialized body.

\section{Manji, Multiculturalism, and Whiteness}

Manji is deeply critical of multiculturalism, arguing that Western society should "grow beyond 'multicultural orthodoxy"' (2011, p. 133). She notes that,

\footnotetext{
${ }^{2}$ The Moral Courage Project is an educational and activist centre which, according to its website, endeavours to "...teach moral courage" which "...means doing the right thing in the face of your fears" (Moral Courage Project, 2020).
} 
as Westerners grovel before multiculturalism, we often act as if anything goes...the more we accommodate to placate, the more their contempt for our "weakness" grows. The ultimate paradox may be that in order to defend our diversity, we'll need to be less tolerant. (Manji, 2005, p. 221)

In critiquing multiculturalism, Manji portrays Muslims as the most egregious violators of Western norms (which are, of course, rooted in whiteness). In so doing, she relies on sensationalized and one-dimensional depictions of Muslims, erasing the diversity of interpretations, experiences, and practices of Muslim communities. For instance, she states "Because Arab norms set infantile expectations of men, something else emerges: a victim mentality that allows Muslim men to commit assorted abuses of power, including rampages against anybody who seemingly humiliates their frail and fragmented sense of self" (Manji, 2011, p. 134). Similarly, in her documentary, Faith Without Fear (2007), Manji concentrates on sensationalized narratives about Muslims, linking them by their shared commitment to Islam, but does not nuance her analysis by considering the social, political, and economic contexts underlying these narratives. Hence, the diversity of Muslim interpretations remains unexplored, with Manji unequivocally asserting that most Muslims are literalists and traditionalists whose practices violate the norms of Western society. Manji presents reductionist perspectives as she juxtaposes the so-called "primitive" Muslim Other against the "enlightened" modern subject (read: white or Westernized body). For Manji, Muslims exist as archetypes, ready to be deployed in crude and unsophisticated forms in pursuit of ideological goals. In her critique of Western (and Canadian) multiculturalism, Manji deploys these one-dimensional depictions - rooted in Orientalist imaginaries - to argue that Muslims require a "reformation" (her word), to "realize our right and responsibility to think" (Manji, 2011, p. 33) and to integrate better with Western norms.

Through her stereotypical depictions of Muslims, Manji erases the specificity of the social, political, economic, and cultural conditions under which Muslims live, including the many mechanisms through which visible Muslims are excluded in Western societies. Manji's silence on these exclusions coupled with her one-dimensional depictions of Muslims shifts the burden of responsibility for political actions onto Muslims. Such discursive maneuvers depict Muslims as barbaric and primitive-Orientalist tropes - with no acknowledgment of the underlying complexities they face. Rendered invisible are the tensions embedded at the heart of Western multicultural societies - between, for instance, the rhetoric of a racially neutral public space and the reality that public space is deeply rooted in the specific racial, ethnic, and religious norms of the dominant elite. 
Significantly, Manji suggests that multiculturalism can best be protected by greater vigilance and "less tolerance," an argument that resonates with Kundnani's depiction of aggressive liberalism and liberal rage (2008, p. 45). Kundnani (2008) notes that contemporary discourses of Western liberalism are cloaked in the language of universalism and a liberal idiom, which perceives Muslims as those most opposed to such norms, an opposition that, some argue, should be forcefully confronted. As Kundnani (2012) observes "Muslims or...certain types of political Muslims come to symbolize the danger of cultural difference and become the focus for a project of producing good, liberal individuals who have absorbed...Western values" (p. 158). These values are coalesced into a sense of "Western identity" that is rooted in the power of whiteness. Challenges to such values evoke powerful and vociferous reactions - "liberal rage" (Kundnani, 2008, p. 45) - against those who are perceived to hold "different values" from so-called "universal" (but invisible) norms of Western society that are grounded in whiteness. The liberal idiom suggests that those not accepting of liberal values - secularism, individualism, gender equality — should be encouraged to accept these values, forcefully if necessary. Such a discursive maneuver is "one of the greatest paradoxes of the liberal ethic of tolerance - namely, the intolerance of intolerance in the name of tolerance" (Fernando, 2014, pp. 224-225). This paradox is evident in Manji's critique of multiculturalism, which reinforces the centrality of whiteness, but cloaks the civilizing mission in humanist language, rendering invisible the power relations at the heart of the mission. Thus, Manji, as a Secular Acceptable Muslim, positions herself ideologically alongside the (white) dominant elite and promotes a monocultural ethos, rendering invisible the fantasy of white space (Hage, 2000), and legitimizing white liberal rage when the fantasy is challenged.

\section{Manji, Gender, and Chivalrous Knights}

Manji, like other Secular Acceptable Muslims, concentrates on gender (in)equality as a central theme in discourses about Muslims, reinforcing the sense that "[s]ecularism is increasingly posited as the best guarantee of women's sexual freedom and equality, and as what distinguishes the West from the woman-abusing rest" (Fernando, 2014, p. 187). Secular Acceptable Muslims are important allies in reinforcing this assumption, which is grounded in Orientalist tropes. Writing about Orientalist depictions of the Muslim woman, Yegenoglu (1998) notes that "the most essential features of the culture are assumed to be inscribed onto her; she is taken as the concrete embodiment of oppressive Islamic traditions" (pp. 97-98). In 
the contemporary era, “the fight to protect women's rights has been transformed into a battle to protect the secular republic" (Fernando, 2014, p. 203). For instance, Manji attributes gender inequality to "tribal culture" (2011, p. 90) and writes that "Muslims exhibit a knack for degrading women" (2005, p. 176). She suggests that according to orthodox Islamic tradition, "shame resides in the woman. Much more so than her brothers, sons or uncles, a woman bears the freight of her entire family's reputation. In effect, men are off the hook" (Manji, 2011, p. 134). Importantly, Manji suggests that gender (in)equality can be understood through a religious or cultural lens which situates Muslims as cultural or religious Others, maintaining that gender inequality amongst Muslims is grounded in "Islamo-tribalism" (2011, p. 90). Her perspectives on gender inequality are rooted both in her critiques of interpretations of Islam and in her foregrounding of individual rights as the pillar of a purportedly enlightened Islam. Such perspectives place responsibility for Muslim women's inequality primarily on the dominance of Muslim men and Muslim traditions.

Manji's views on gender do not challenge the fundamental structural violences underlying gender inequality, instead placing the responsibility on the "dangerous Muslim man" (Razack, 2008) and his so-called oppressive traditions. Embedded in Manji's perspectives on gender inequality amongst Muslims is the reductionist imaginary of a benevolent, secular West juxtaposed against a primitive, barbaric, and oppressed Islam. Such depictions, rooted in Orientalist imaginaries, enable Secular Acceptable Muslims such as Manji to situate themselves as "chivalrous knights of civilization" (Jiwani, 2009), bringing equality and freedom to "helpless maidens" (Jiwani, 2009). Secular Acceptable Muslims therefore complicate the eternal triangle (Razack, 2008) because they are perceived as civilized subjects who rescue Muslim women from oppressive traditions. Such a positioning of Secular Acceptable Muslims as knights saving Muslim women erases the racialized logic underlying the rescue motif and how such a motif serves the ideological goals of empire, with the state using the spectre of the oppressed Muslim woman to regulate the lives of Muslims. Hence, Acceptable Muslims stand as sentries at the boundaries of the nation-state, ensuring that these racialized borders of acceptability position some bodies outside, and others within, the nation. Gender is the terrain on which they most often stand and from which Manji and other Secular Acceptable Muslims perform the dance of loyalty to the ideological goals of the (white) Canadian nation-state.

Manji, like other Acceptable Muslims, is celebrated in Canada and internationally. She represents the face of the "courageous" Muslim, who dares to dissent from Muslim orthodoxy. In an era of white rage, she, like other Secular Acceptable Muslims, legitimizes the rage against those perceived to be rejecting "universal" (read: white, Western) values and 
identity. Indeed, Manji and others like her are celebrated, I suggest, precisely because they reinforce the centrality of whiteness in the nation-state, while they simultaneously inoculate the state from charges of racism. Hence, Secular Acceptable Muslims stand at the boundaries of the nation, signalling that the racial and religious Other can be surveilled, policed, and, if necessary, expelled from political and social community. White rage against those refusing to be integrated - forcefully if necessary - is thus legitimized and rendered palatable through the insider reports of such Acceptable Muslims.

\section{Reanimating Standards of Acceptability: Little Mosque on the Prairie and Multiculturalist Acceptable Muslims}

\section{Introduction}

Little Mosque on the Prairie (LMOP) is a Canadian (CBC) television sitcom (20072012), created by Zarqa Nawaz - who is a journalist, writer, and comedian - and produced by Westwind Pictures. The title of LMOP riffs on Little House on the Prairie, a 1970s American serial drama that presented a nostalgic and bucolic account of white settlers in the US MidWest. $L M O P$ is situated in the fictional town of Mercy, Saskatchewan, and is advertised as "an unabashedly funny look at the congregation of a rural mosque and their attempts to live in harmony with the often skeptical, even downright suspicious, residents of their little prairie town" (CBC, 2007). The sitcom was popular, attracting 2.1 million viewers for its first episode and has been broadcast in numerous countries (MacDonald, 2007). Previous scholarship on $L M O P$ has praised it for challenging Orientalist stereotypes, opening up a space to discuss Muslim issues, and reaffirming Canada's multicultural ethos (Cañas, 2008; Conway, 2017; Dakroury, 2012; Eid, 2011; Hirji, 2011). While the sitcom challenges Orientalist stereotypes, I argue that it also reinforces hegemonic messages in the Canadian national imaginary, reanimating notions of acceptability, leaving unchallenged the whiteness at the centre of the national narrative. $L M O P^{\circ}$ s creator, Nawaz (who I argue is a Multiculturalist Acceptable Muslim), reinforces such standards of acceptability in her own work. The sitcom idealizes Multiculturalist Acceptable Muslims and, while celebrating Canada's multicultural ethos, reinforces the contours of the national imaginary, a scaffolding that is deeply racialized. By not challenging the whiteness at the heart of the national imaginary, $L M O P$ reinforces the idea that "acceptable" Muslims can be integrated if they embrace the norms of Western society. I suggest that LMOP thus illuminates the boundaries 
of "acceptable" Canadian citizenship, reinforcing the multicultural ideals at the heart of the nation, but rendering invisible the power of whiteness that animates the national narrative.

$L M O P$ reflects a Canadian landscape in which some (acceptable) visibly Muslim bodies are well integrated in Western society. The sitcom exalts idealized Muslims who remain committed to their faith while integrating within Canadian society. While this is not, in itself, an unusual aim, what is fascinating about Multiculturalist Acceptable Muslims is how comfortably they echo Canada's multicultural ethos and its image of benevolence, without challenging the fundamental structures of power and whiteness at the heart of the national narrative. In particular, I show that LMOP idealizes a particular type of Muslim-a Multiculturalist Acceptable Muslim - that reflects the standards of acceptability most valued in the Canadian national space. While I focus predominantly on LMOP, Nawaz's perspectives are never far from the sitcom's representations; thus, I also refer to Nawaz's ideas in my analysis.

\section{Little Mosque on the Prairie's Reanimation of Canada's Multicultural Fantasy}

In contrast to Secular Acceptable Muslims, Multiculturalist Acceptable Muslims, as represented on $L M O P$, celebrate and uncritically embrace Canadian multiculturalism. The sitcom attempts to normalize the differences between Muslim and non-Muslim Canadians so that Canadians will realize that "although different, we are all surprisingly similar" (CBC, 2007). The sitcom uses humour to reach across religious and cultural divides to "encourage non-Muslims to question their preconceptions and understand Muslims as more like themselves...in effect, to 'translate' Muslims for non-Muslims" (Conway, 2017, p. 10). The discourse of multiculturalism is centrally embedded in the sitcom, in which narratives and characters are situated within the Canadian multicultural paradigm, underlining the notion that Muslims, under the right conditions, can integrate into this paradigm. The sitcom's celebration of the multicultural narrative conveys the multicultural illusion that Canadian society can (and does) treat all subjects equally without questioning its veracity for all bodies in the nationstate. Hence, LMOP's ethos communicates to audiences that Muslims and non-Muslims are fundamentally similar and that they live in an equal and accepting society. The sitcom's characters engage both in activities that are stereotypically Canadian (e.g., camping, curling, watching football), and those designed to educate non-Muslims about Islam (e.g., Ramadan, Eid, gender norms). In both cases, the sitcom underlines the ideal that Muslims and nonMuslims can live together harmoniously, despite their religious/cultural differences. 
Embedded in these narratives are the terms of the multicultural compact: the negotiation of cultural difference through compromise and patience, ensuring that "acceptable" cultural traditions can co-exist in the community.

$L M O P^{\prime}$ s characters provide insight into the ideological themes of the sitcom, illuminating the unstated consensus about Canadian multiculturalism. The characters "stand at the very heart of the sitcom, communicating hegemonic messages and values...and reinforcing the Canadian 'consensus' (often unspoken) on the benefits of multiculturalism" (Kassam, 2015 , p. 615). While characters on the sitcom are ethnically and racially diverse (a positive change from Orientalist stereotypes), diversity on the sitcom remains fixated on ethnic diversity, reinforcing the multiculturalist idea that difference is constituted primarily in cultural terms. Centrally located in LMOP are Amaar Rashid and Rayyan Hamoudi-I argue that they are Multiculturalist Acceptable Muslims - who are depicted as idealized "modern" Muslims and role models for others. These characters are intelligent, professional, and committed to practicing faith within a secular, multicultural paradigm. Amaar and Rayyan articulate liberal interpretations of Islam and reject orthodox or extreme interpretations, practising their faith within Canadian societal norms. They embody the perspectives of Multiculturalist Acceptable Muslims whose commitment to a "moderate and liberal" Islam is married to their commitment to the multicultural fantasy of Canadian society - that people of differing religious and cultural traditions are embraced equally in the public sphere with little (or no) mention of the centrality of whiteness in the national imaginary. Notably absent from the sitcom's regular characters (some more traditional than Amaar and Rayyan) are either extremist Muslims or progressive voices resisting the foundational norms of the Canadian national narrative. Interestingly, when Marlon, a new convert, joins Mercy’s Muslim community midway through the first season, most characters are disturbed by his zealous adherence to orthodox norms (Rae \& Kennedy, 2007). In the end, the community encourages Marlon to leave the Muslim community, illuminating its (and the sitcom's) rejection of orthodox norms and its celebration of "moderate" approaches to the practice of Islam, an approach more acceptable within the construct of Canadian multicultural society.

The language of multiculturalism is an important dimension of the sitcom. For instance, in Season 4, Yasir (one of the characters), having broken a statue of Jesus in the church, secretly orders another one, only to discover that it is black. Sarah, Yasir's wife and a white converted Muslim exclaims, “He’s Black! Oh, this is terrible...I mean, not that he's Black. It's...it's great that he is Black... I mean, not great for us... I mean, for the people who see him that way... I am not a racist" (Nawaz \& Wright, 2009). She later adds, "We didn't mean to break the normal one...I mean...I mean... the white one... I mean, not that white is 
normal... I am not a racist" (Nawaz \& Wright, 2009). In repeating "I am not a racist," Sarah aligns herself with "good" Canadians, who see themselves as "not racist." Such a discourse reflects the (white) Canadian anxiety about being perceived as racist, while underlining (and challenging) the normality of whiteness in society. Such examples, among others, illuminate the celebration of multiculturalist discourse in $L M O P^{\prime}$ s narratives. Indeed, Nawaz confirms this perspective, saying that the sitcom "reflects a multicultural society that is a success rather than a failure" (Nawaz, 2015).

Nawaz's celebration of Canadian multiculturalism is evident in her own commentaries. As she observes,

I was always very secure in the feeling that Canada was home and I was Canadian.... I am considered one of few Muslims in the world who have successfully bridged the worlds of faith and comedy. But I would have not been able to do this had I lived anywhere else in the world.... It was only in Canada, where I truly felt I belonged and was cherished as a Muslim. (Nawaz, 2015)

Nawaz situates Canada as her ideal and reinforces Canada's sense of itself as a benevolent and accepting country. However, Nawaz's (and $L M O P^{\prime}$ s) embrace of Canada's multicultural ethos leaves many silences. She does not acknowledge, for instance, that her security is not necessarily shared by other bodies in Canada. She thus leaves unacknowledged the differential citizenship of subjects and she renders invisible the racial stratification of Canadian society. Through this silence, she leaves unacknowledged her complicity as a boundary-marker in racialized notions of citizenship; hers is the Acceptable Muslim body which gains qualified inclusion in the Canadian national imaginary. Significantly, Nawaz does not acknowledge the colonial reality of Canadian society - that the nation-state is founded on colonial theft of Indigenous lands and the ongoing contemporary structural violence built into the national imaginary. Such structural violence is embedded both in movements of ever-assertive white rage and in the debates amongst liberals about the so-called "limits of multiculturalism." Through her perspectives, Nawaz's acceptable subject-hood can, therefore, be harnessed by the nation-state in its technologies of power through which the racial and religious Other is surveilled, regulated, and excluded from the public sphere, her complicity rendering invisible the state's structural violences, while upgrading its multicultural credentials. 


\section{Little Mosque on the Prairie, Gender, and the Politics of Authenticity}

Like Secular Acceptable Muslims, Multiculturalist Acceptable Muslims — such as those depicted on $L M O P$ - centralize gender and the experiences of Muslim women. The sitcom, through the centrality of its female characters, does challenge classic Orientalist tropes about Muslim women as veiled, exotic, submissive, oppressed, and traditional. That such strong Muslim women appear on mainstream television is a positive development, reflecting Nawaz's focus on gender as evidenced by her own work (Nawaz, 2005a, 2005b, 2014, 2015). Despite these positive developments, both in Nawaz's work and in LMOP, I suggest that the perspectives of Multiculturalist Acceptable Muslims fall within the parameters of acceptability in the Canadian national imaginary. While female characters challenge gender norms on LMOP, they nonetheless reinforce the notion of an "authentic" Muslim woman (Hirji, 2011), a discursive strategy which reinforces "recognizable archetypes for people from other origins and faith traditions" (Conway, 2017, p. 51). For instance, many of the significant female characters on the sitcom wear hijabs, do not date, and generally live as "good" Muslim women, even if they sometimes struggle with gendered norms. The sitcom reaffirms, perhaps inadvertently, the idea of a "good" or "proper" Muslim woman, an unrealistic construct to represent the diverse realities of Muslim women's lives. By rendering Muslim women's issues as hypervisible and yet reinforcing an implied Muslim norm, the sitcom reaffirms a key feature of gendered Orientalist thought — that gender is presumably the most important site for discourse about Muslims.

The acceptance and reinforcement of an implied Muslim gendered norm constrains the discursive space for diversity - for interpretation, behaviour, choices, politics, and lifestylesfor Muslim women. The sitcom reinforces the idea that "good" Muslim women are liberated from orthodox constraints of faith, and/or wish to "liberate" the "imperilled Muslim woman" (Razack, 2008). Hence, while LMOP challenges Orientalist stereotypes about Muslim women, the reliance on an idealized and authentic Muslim norm - the politics of authenticity (Kassam, 2018) - reinforces that gender is the terrain on which ideological battles about Muslims are usually waged. Ultimately, the sitcom does not articulate a nuanced gender politics and, through strategic essentialism, limits the discursive space for Muslim women to interpret, practice, and express their faith in ways that reflect the tremendous diversity of Muslim lives.

While Multiculturalist Acceptable Muslims are more nuanced than their Secular Acceptable Muslim counterparts, these perspectives remain nonetheless mired in Orientalist imaginaries. In different ways, Acceptable Muslims place the responsibility for Muslim 
women's inequality on the dominance of Muslim men, rather than on the structural violences at the heart of patriarchal societies. Such perspectives fortify the eternal triangle (Razack, 2008) without challenging these foundational structural violences underlying gendered inequality (in all societies, both Muslim and non-Muslim). While Multiculturalist Acceptable Muslims, such as Nawaz and some LMOP characters (particularly Rayyan) interrupt the "saving" discourse by being vocal and strong Muslim women they, like Secular Acceptable Muslims, operate within a limited set of norms that situate gender at the heart of discourses about Muslims, which are grounded in Orientalist imaginaries. In this way, all Acceptable Muslims, both Secular and Multiculturalist, function (or are harnessed) as civilized subjects who rescue imperilled Muslim women, a positioning that both erases the racialized logic at the heart of the rescue motif and situates the rescue motif as an act of benevolence, not of power. Standing on the terrain of Muslim women's presumed inequality, Acceptable Muslims symbolize (or are used to symbolize) the guarding of the boundaries of acceptability with the Canadian imaginary.

\section{Conclusion: The Ideological Implications of Acceptable Muslims}

My analysis of Acceptable Muslims, as evidenced in the two case studies considered, illuminates the ideological work performed by such archetypal figures in the Canadian national imaginary, especially in an era of increasingly virulent white rage. Such Acceptable Muslims personify key standards of acceptability that enable them to find qualified inclusion in the nation-state, while being celebrated as icons of Canadian multicultural success. In this paper, I focus especially on two attributes of acceptability that position Acceptable Muslimsin their Secular and Multiculturalist archetypes - to support imperial feminism and to celebrate Canada's multicultural ideals.

Acceptable Muslims nuance the saving discourse and support imperial feminism, either explicitly (Secular) or implicitly (Multiculturalist), attempting to "save" Muslim women from presumed oppression. The saving discourse is based on significant power disparities between Muslim women (who apparently cannot be trusted to define their own practices and lives) and Western subjects (who are entrusted with presumably "superior" civilizational values with the power to "help" others who are oppressed). In this respect, Acceptable Muslims both nuance the eternal triangle (Razack, 2008) and, implicitly or explicitly, become the newest members of the "chivalrous knights" (Jiwani, 2009) seeking to liberate Muslim women from their presumed oppression. Such a positioning lends credence to 
those who argue that the "imperilled Muslim woman" (Razack, 2008) must be rescued from the presumably oppressive traditions of "barbaric Muslim men" (Razack, 2008). By their positioning as "acceptable" Muslims critiquing such gendered norms, Acceptable Muslims find qualified inclusion in the national imaginary. They are celebrated as "brave voices" challenging their communities, voices that can then be harnessed as public advocates of Western norms. The liberal-multicultural state requires the presence of such assimilated foreigners - or "familiar strangers" (Ahmed, 2000) — to reconfirm its presumably race-neutral benevolence, and to prove that Western normative values have universal appeal. Dabashi (2011) notes that "empire thrives on the stories it tells...These stories need exotic seasoning and the native informers provide them" (p. 128). I suggest that, in an era of white rage, these Acceptable Muslims are situated as acceptable, reasonable, and recognizable precisely because they reinscribe the ideological underpinnings of the Canadian nation-state, rooted both in whiteness and in gendered Orientalist imaginaries.

Canadian multiculturalist discourse is deeply engrained in the Canadian national mythology, and Acceptable Muslims — both Secular and Multiculturalist — provide ideological support for the project of Canadian multiculturalism rooted in whiteness. Perspectives of Acceptable Muslims resonate with ongoing debates in the public sphere about multiculturalism, with one side protesting its excesses, and the other embracing its ethos. In either case, difference is constituted in cultural terms; lack of integration is associated with individual cultural differences, rather than with systemic marginalization. Hence, multicultural policy "in emphasizing culture...suppress[es] public discussion of the racism, both institutional and personal, which bar[s] the full participation of people of colour within the economic and socio-political establishment" (Thobani, 2007, p. 156). These perspectives map out what counts as legitimate public discourse about multiculturalism, race and racism, ruling out discussions about institutional and systemic exclusion of racialized peoples. Challenges by racialized peoples to systemic marginalization are perceived to be "in bad form, or, worse, as acting in bad faith" (Thobani, 2007, p. 163).

Such challenges to marginalization are rooted in white rage which (in a fit of white fragility) is directed at racialized Others who are perceived to have received "too much" from the nation-state or who are perceived to threaten "our" (read: white) norms. Secular Acceptable Muslims are explicit that multiculturalism has "gone too far" and align themselves with hard-line white Canadians who argue for a return to whiteness. Multiculturalist Acceptable Muslims, on the other hand, subscribe to the cultural framing of differences, aligning themselves with white liberals, who argue that multiculturalism should be celebrated, but do not challenge the fantasy of white space (Hage, 2000) underlying the national 
imaginary. That both types of Acceptable Muslims ultimately support, explicitly or implicitly, the fantasy of white space is perhaps one of the reasons that Acceptable Muslims are prominent in Canadian public discourse. Acceptable Muslims reinforce the paradigm and the assumptions underlying the national narrative in the Canadian nation-state - that integration (or lack thereof) is linked to individual cultural differences rather than systemic barriersthereby reconfirming (but rendering invisible) the whiteness of the public sphere.

In an era of (re)assertive white rage, Acceptable Muslims, both Secular and Multiculturalist, signify the racialized boundaries of acceptability in Canadian society and render invisible the unequal access to citizenship privileges in the nation-state. Acceptable Muslim figures are those with commensurable difference, recognized in the national psyche as assimilable or "tolerable" subjects granted inclusion in the nation. These figures are juxtaposed against the racial and religious Other, with non-commensurable difference, who can then be policed or excluded from society. The Acceptable Muslim demarcates the boundary between the (white) exalted subject (Thobani, 2007), the citizen with qualified inclusion (the Acceptable Muslim) and the non-acceptable body (the racial/religious Other) who is marked for surveillance, marginalization, and exclusion. In this respect, Acceptable Muslims police the boundaries of the nation, signalling that inassimilable Muslims (and Indigenous and other racialized bodies) can continue to be surveilled, policed, and kept outside the political community of legitimate (white) citizens. Acceptable Muslims thereby reconfirm the racial logic that is at the heart of the national imaginary. Against the backdrop of white rage, such an Acceptable Muslim figure is an important element of the state's technology of power, enabling its governmentality to be directed at racial, religious, and "intolerable" Others without charges of racism, and dressing its whiteness in the cloak of multiculturalism while simultaneously continuing to marginalize, exclude, and expel Indigenous and racialized bodies. By so doing, the state harnesses (and celebrates) the perspectives of Acceptable Muslims to inoculate itself from charges of anti-Muslim (or any other kind of) racism.

Acceptable Muslims mask the tensions and contradictions entrenched in the Canadian national imaginary and render invisible the constructed mythologies at work (re)producing the racialized and gendered fissures at the heart of the Canadian nation-state. In this way, Acceptable Muslims mediate and "defer the contradictions of republican citizenship" (Fernando, 2009, p. 381), erasing how so-called universal (and supposedly race-neutral) citizenship is grounded in specific racial, cultural, and religious traditions. Such an erasure is significant in a settler state such as Canada, in which the colonial legacy is invisibilized and a disavowal of contemporary racial (and racist) structures continues unabated. By masking these 
contractions and rendering invisible the racialized nature of citizenship - and the unequal access to its privileges-Acceptable Muslims render invisible the fantasy of white space (Hage, 2000) at the heart of the settler nation-state. They thus render whiteness more palatable, masking this whiteness in the more benevolent grammars of multiculturalism, gender equality, and secularism. In this manner, Acceptable Muslims enable, consciously or unconsciously, the proponents of whiteness to couch their arguments in the supposedly universal languages of Western norms rather than the explicitly racialized (and racist) norms that they seek to uphold.

\section{References}

Ahmed, S. (2000). Strange encounters: Embodied Others in the post-coloniality. New York, NY: Routledge.

Alsultany, E. (2012). Arabs and Muslims in the media: Race and representation after 9/11. New York, NY: NYU Press.

Anderson, B. (1983). Imagined communities. Brooklyn, NY: Verso Publishers.

Balibar, E., \& Wallterstein, I. (1988/2005). Race, nation, class: Ambiguous identities. Brooklyn, NY: Verso Publishers.

Bayoumi, M. (2010). The God that failed: The Neo-Orientalism of today's Muslim commentators. In A. Shryock (Ed.), Islamophobia/Islamophilia: Beyond the politics of enemy and friend (pp. 79-93). Bloomington, IN: Indiana University Press.

Cañas, S. (2008). The Little Mosque on the Prairie: Examining (multi) cultural spaces of nation and religion. Cultural Dynamics, 20(3), 195-211.

CBC. (2007). Little Mosque on the Prairie press kit.

Conway, K. (2017). Little Mosque on the Prairie and the paradoxes of cultural translation. Toronto, ON: University of Toronto Press.

Dabashi, H. (2011). Brown skin, white masks. Winnipeg, MB: Fernwood Publishing.

Dakroury, A. (2012). Toward media reconstruction of the Muslim imaginary in Canada: The case of the Canadian Broadcasting Corporation's sitcom Little Mosque on the Prairie. In J. Zine (Ed.), Islam in the hinterlands: Muslim cultural politics in Canada (pp. 161181). Vancouver, BC: UBC Press.

Darling, G., Donnelly, C., \& Magee, A. (Executive Producers). (2007-2012). Little mosque on the prairie [Television series]. Toronto, ON: Canadian Broadcasting Corporation (CBC). 
Eid, M., \& Khan, S. (2011). A new look for Muslim women in the Canadian media: CBC's Little Mosque on the Prairie. Culture and Communication, 4(2), 184-202.

Fernando, M. (2009). Exceptional citizens: Secular Muslim women and the politics of difference in France. Social Anthropology, 17(4), 379-392.

Fernando, M. (2014). The republic unsettled: Muslim French and the contradictions of secularism. Durham, NC: Duke University Press.

Goldberg, D.T. (2009). The threat of race: Reflections on racial neoliberalism. Malden, MA: Blackwell Publishing.

Hage, G. (2000). White nation: Fantasies of white supremacy in a multicultural society. New York, NY: Routledge.

Hirji, F. (2011). Through the looking glass: Muslim Women on television - An analysis of 24, Lost, and Little Mosque on the Prairie. Global Media Journal: Canadian Edition, $4(2), 33-47$.

Jiwani, Y. (2009). Helpless maidens and chivalrous knights: Afghan women in the Canadian press. University of Toronto Quarterly, 78(2), 728-744.

Jiwani, Y. (2011a). Hierarchies of worthiness: Women and victimhood in the Canadian media. Briar Patch, 40(3), 15-20.

Jiwani, Y. (2011b). Trapped in the carceral net: Race, gender and the "War on Terror". Global Media Journal: Canadian Edition, 4(2), 13-31.

Jiwani, Y. (2014). Posthumous rescue: The Shafia young women as worthy victims. Girlhood Studies, 7(1), 27-45.

Jiwani, Y. (2017). Orientalizing "War Talk": Representations of the gendered Muslim body post 9-11 in The Montreal Gazette. In R. S. Coloma \& G. Pon. (Eds.), Asian Canadian Studies Reader (pp. 202-221). Toronto, ON: University of Toronto Press.

Karim, K. H. (2000). Islamic peril: Media and global violence. Montreal, QC: Black Rose Books.

Kassam, S. (2015). "Settling" the multicultural nation-state: Little Mosque on the Prairie and the figure of the "moderate Muslim". Social Identities, 21(6), 606-626.

Kassam, S. (2018). Standing on guard for thee: The Acceptable Muslim and boundaries of racialized inclusion. (Unpublished doctoral dissertation). University of Toronto, Ontario.

Kundnani, A. (2008). Islamism and the roots of liberal rage. Race and Class, 50(40), 40-68.

Kundnani, A. (2012). Multiculturalism and its discontents: Left, right and liberal. European Journal of Cultural Studies, 15(2), 155-166. 
Kundnani, A. (2014). The Muslims are coming!: Islamophobia, extremism and the domestic war on terror. Brooklyn, NY: Verso Publishers.

Lentin, A. (2008). Europe and the silence about race. European Journal of Social Theory, 11(4), 487-503.

Lentin, A. (2015). What does race do? Ethnic and Racial Studies, 38(8), 1401-1406.

MacDonald, G. (2007, May 9). Little Mosque on the Champs Elysees. The Globe and Mail, p. R1.

Maira, S. (2009). "Good" and "bad" Muslim citizens: Feminists, terrorists, and U.S. orientalism. Feminist Studies, 35(3), 631-636.

Mamdani, M. (2004). Good Muslim, bad Muslim: America, the Cold War and the roots of terror. New York, NY: Pantheon Books.

Manji, I. (2005). The trouble with Islam today. Toronto, ON: Vintage Canada.

Manji, I. (Writer), \& McLeod, I (Director). (2007). Faith without fear: Irshad Manji's quest [Video recording]. 90th Parallel Film \& Television Productions, and the National Film Board of Canada.

Manji, I. (2011). Allah, liberty and love: The courage to reconcile faith and freedom. Toronto, ON: Vintage Canada.

Manji, I. (2019). Don't label me: An incredible conversation for divided times. New York, NY: St. Martin's Press.

Moral Courage Project. (2020). Moral Courage Project: Why? Retrieved from https://moralcourage.com/why/

Naber, N. (2008). Arab Americans and U.S. racial formations. In A. Jamal \& N. Naber (Eds.), Race and Arab Americans before and after 9/11 (pp. 1-45). Syracuse, NY: Syracuse University Press.

Nawaz, Z. (Writer \& Director). (2005b). Me and the Mosque [Film]. National Film Board of Canada.

Nawaz, Z. (Writer) \& Wright, S. (Director). (2009). Handle with care [Television series episode]. In M. Darling, C. Donnelly \& A. Magee (Executive Producers). Little mosque on the prairie. Toronto, ON: Canadian Broadcasting Corporation (CBC).

Nawaz, Z. (2014). Laughing all the way to the Mosque. Toronto, ON: Harper Collins.

Nawaz, Z. (2015, September 16). Growing up Muslim: An individual story, a universal tale. The Globe and Mail. Retrieved from www.theglobeandmail.com

Rae A. (Writer), \& Kennedy, M. (Director). (2007). The convert [Television series episode]. In M. Darling, C. Donnelly \& A. Magee (Executive Producers). Little mosque on the prairie. Toronto, ON: Canadian Broadcasting Corporation (CBC). 
Rana, J. (2007). The story of Islamophobia. Souls, 9(2), 148-161.

Rana, J. (2016). The racial Infrastructure of the terror-industrial complex. Social Text, 34(4), 111-138.

Razack, S. (1999). Making Canada white: Law and the policing of bodies of colour. Canadian Journal of Law and Society, 14, 159-184.

Razack, S. (2001). Looking white people in the eye: Gender, race and culture in courtrooms and classrooms. Toronto, ON: University of Toronto Press.

Razack, S. (2008). Casting out: The eviction of Muslims from Western law and politics. Toronto, ON: University of Toronto Press.

Razack, S. (2012). “We didn't kill 'em, we didn't cut their head off”: Abu Ghraib revisited. In D. Martinez Hosang, O. LaBennett, \& L. Ulido (Eds.), Racial formation in the twentyfirst century (pp. 217-245). Los Angeles, CA: University of California Press.

Razack, S. (2014). The manufacture of torture as public truth: The case of Omar Khadr. In S. Perera \& S. H. Razack (Eds.), At the limits of justice: Women of colour on terror (pp. 57-85). Toronto, ON: University of Toronto Press.

Razack, S. (2018). "A catastrophically damaged gene pool": Law, white supremacy, and the Muslim psyche. In D. Sohail \& J. Rana (Eds.), With stones in our hands: Writings on Muslims, racism, and empire (pp. 183-200). Minneapolis, MN: University of Minnesota Press.

Razack, S. (Ed.) (2002). Race, space and the law: Unmapping a white settler society. Toronto, ON: Between the Lines.

Said, E. W. (1978/2003). Orientalism. Toronto, ON: Random House.

Said, E. W. (1981). Covering Islam: How the media and the experts determine how we see the rest of the world. Toronto, ON: Random House.

Sharify-Funk, M. (2010). Dissident Muslims, dissonant times. Inroads, 26, 132-142.

Sharify-Funk, M. (2013). Pervasive anxiety about Islam: A critical reading of contemporary "clash" literature. Religions, 4, 443-468.

Shryock, A. (2010). Islam as an object of fear and affection. In A. Shryock (Ed.), Islamophobia/Islamophilia: Beyond the politics of enemy and friend (pp. 1-25). Bloomington, IN: Indiana University Press.

Thobani, S. (2007). Exalted subjects: Studies in the making of race and nation in Canada. Toronto, ON: University of Toronto Press.

Thobani, S. (2014). Fighting terror: Race, sex and the monstrosity of Islam. In S. Perera \& S. H. Razack (Eds.), At the limits of justice: Women of colour on terror (pp. 472-496). Toronto, ON: University of Toronto Press. 
Van Dijk, T. A. (2008). Discourse and power. New York, NY: Palgrave MacMillan.

Volpp, L. (2002). The citizen and the terrorist. UCLA Law Review, 49(5), 1575-1600.

Volpp, L. (2005). Impossible subjects: Illegal aliens and alien citizens. Michigan Law Review, $103(6), 1595-1630$.

Volpp, L. (2007a). Citizenship undone. Fordham Law Review, 75, 2579-2586.

Volpp, L. (2007b). The culture of citizenship. Theoretical Inquiries in Law, 8(2), 571-602.

Volpp, L. (2012). Imaginings of space in immigration law. Law, Culture and the Humanities, $9(3), 456-474$.

Yegenoglu, M. (1998). Colonial fantasies: Towards a feminist reading of Orientalism. Cambridge, UK: Cambridge University Press.

Yuval-Davis, N. (2006). Belonging and the politics of belonging. Patterns of Prejudice, 4O(3), 197-214.

Zine, J. (2012). Unsettling the nation: Gender, race, and Muslim cultural politics in Canada. In J. Zine (Ed.), Islam in the hinterlands: Exploring Muslim cultural politics in Canada (pp. 41-60). Vancouver, BC: UBC Press. 